\title{
OCHRATOXIN A IN WINES AND GRAPE JUICES COMMERCIALIZED IN THE CITY OF SÃO PAULO, BRAZIL
}

\author{
Luzia Shundo; Adriana P. de Almeida; Janete Alaburda; Valter Ruvieri; Sandra A. Navas; Leda C.A. Lamardo; \\ Myrna Sabino*
}

Instituto Adolfo Lutz, Seção de Química Biológica, São Paulo, SP, Brasil

Submitted: December 12, 2005; Returned to authors for corrections: March 30, 2006; Approved: July 18, 2006

\begin{abstract}
During the summer of 2005, a total of 101 samples of wines and grape juices purchased from supermarkets and retail stores in São Paulo city were analysed for the presence of Ochratoxin A (OTA). OTA was evaluated in 29 red wines and 38 grape juices produced in Brazil and in 34 imported red wines (from Argentina, Chile, Uruguay, France, Italy, Portugal, Spain and South Africa). OTA was extracted in an immunoaffinity column and detected by HPLC with fluorescence detection, according to EN 14133/2003. The detection and quantification limits established were 0.01 and $0.03 \mathrm{ng} / \mathrm{mL}$, respectively. The recoveries for wine samples were $94.1,82.5,86.1 \%$ and the relative standard deviation were $6.10,1.03,4.11 \%$ at levels of $0.03,2.0,5.0 \mathrm{ng} / \mathrm{mL}$, respectively. For grape juice, the recovery was $86.2 \%$ and the RSD was $2.01 \%$ at a level of $0.4 \mathrm{ng} / \mathrm{mL}$. OTA contamination was found in nine of the 29 Brazilian red wines with levels ranging from 0.10 to $1.33 \mathrm{ng} / \mathrm{mL}$ and in 18 of the 34 imported red wines with levels ranging from 0.03 to $0.32 \mathrm{ng} / \mathrm{mL}$. OTA was not detected in any of the grape juice samples analysed. Although the results from the wine samples analysed for the presence of OTA were below to the limits established by EC 123/2005 (2.0 ng/mL), low and continuous exposure to this mycotoxin could be a risk to human health.
\end{abstract}

Key words: Ochratoxin A, red wine, grape juice, immunoaffinity colunm, HPLC determination

\section{INTRODUCTION}

Ochratoxin A (OTA) is a mycotoxin produced by a single Penicillium species, Penicillium verrucosum, by Aspergillus ochraceus and several related Aspergillus species, and by Aspergillus carbonarius with a small percentage of isolates the closely related Aspergillus niger (25). It has been detected in different kinds of foods and beverages, including wine and grape juice.

Wine is a product widely consumed by adults in both developed and developing countries (24). In Europe, it has been estimated that wine is the second most important source of OTA in the diet after cereals (22). Several studies have demonstrated the presence of this mycotoxin in wines at low but variable levels, mainly in those produced in Mediterranean wine-growing regions of Europe, North and South Africa $(2,4,5,10,13,14,18,19$,
$22,23,26)$. It has also been found in musts and grape juices $(20)$. The presence of OTA in grape juice is a matter of concern because it may be the main source of OTA intake by children (26).

OTA has been shown to be nephrotoxic and hepatotoxic, causing kidney and liver cancer in mice and rats $(21,25)$. The nephrotoxicity in monogastric animals (e.g. porcine nephropathy) is well documented and results significant economic losses in the swine and poultry industries. OTA has been associated with Balkan Endemic Nephropathy and the development of urinary tract tumors in humans $(3,15,17,26)$. It has also been described as genotoxic, immunotoxic, teratogenic and neurotoxic in laboratory animals. In 1993, the International Agency for Research on Cancer (IARC) classified OTA (Group B) as a possible carcinogen to humans (12).

The Comission Regulation EC 123/2005 (7) has set limits for OTA in wine and grape juice at $2.0 \mathrm{ng} / \mathrm{mL}$. This has been

*Corresponding Author. Mailing address: Instituto Adolfo Lutz, Seção de Química Biológica, Av. Dr. Arnaldo, 355, Cerqueira César. 01246-902, São Paulo, SP, Brasil. Tel.: (+5511) 3068-2921, Fax: (+5511) 3062-5363. E-mail: mysabino@ial.sp.gov.br 
applied to products produced from 2005 onward. In Brazil, no regulatory limits for OTA have been adopted and there is only a limited data about this mycotoxin in food, cereals and beverages.

The aim of this study was to obtain further data concerning the occurrence of OTA in locally produced red wines and grape juice and in imported red wines commercialized in the city of São Paulo, Brazil.

\section{MATERIALS AND METHODS}

\section{Samples}

The wines and grape juice were purchased from supermarkets and retail stores in the city of São Paulo, Brazil during the summer of 2005. Wine samples were chosen considering different Brazilian wine-producing regions and some of the most important wine-producing countries. Both were chosen considering popular prices. A total of 101 samples were analysed: 29 Brazilian and 34 imported red wines, 38 grape juices produced in Brazil were also analysed. Bottles were stored at room temperature and opened only before analysis. All information on the samples was taken from the labels.

\section{Standard and Reagents}

OTA standard was purchased from Sigma (St. Louis, MO, USA). Acetonitrile and methanol were of HPLC grade from Merck. Glacial acetic acid, sodium chloride and sodium hydrogen carbonate were purchased from Merck and polyethylene glycol (PEG 8000) from Oxiteno. The diluting solution was prepared by dissolving $10 \mathrm{~g}$ of polyethylene glycol and $50 \mathrm{~g}$ of sodium hydrogen carbonate in $1000 \mathrm{~mL}$ of water, and the washing solution was prepared by dissolving $25 \mathrm{~g}$ of sodium chloride and $5 \mathrm{~g}$ of sodium hydrogen carbonate in 1000 $\mathrm{mL}$ of water.

OTA stock solution was prepared in toluene-acetic acid (99:1, v/v). The concentration was determined according to AOAC (1), checked with UV spectrophotometry at $333 \mathrm{~nm}$, using $\varepsilon=5440 \mathrm{~cm}^{-1} \mathrm{~mol}^{-1} . \mathrm{L}$. Working solution was prepared by appropriate dilution in toluene-acetic acid (99:1, v/v) for the recovery tests and calibration curve. The solutions were stored from $-15^{\circ} \mathrm{C}$ until to $-20^{\circ} \mathrm{C}$ and protected from light.

\section{Sample preparation and immunoaffinity clean-up}

Based on the method described in EN 14133 (9), wine samples $(40 \mathrm{~mL})$ were added to $40 \mathrm{~mL}$ of the diluting solution and mixed vigorously. This solution was filtered through a glass microfibre and $40 \mathrm{~mL}$ of this filtered solution was passed through an immunoaffinity column (Ochraprep, R-Biopharm Rhône Ltd). The column was washed with $10 \mathrm{~mL}$ of washing solution and then with $10 \mathrm{~mL}$ of water to remove extraneous non-specific material. Following this, the OTA bound to the antibody was released through the elution with $2.0 \mathrm{~mL}$ of methanol. The eluate was evaporated to dryness using a stream of $\mathrm{N}_{2}$. This residue was reconstituted in the $300 \mu \mathrm{L}$ HPLC mobile phase and $20 \mu \mathrm{L}$ (in triplicate) of which was injected into the chromatographic equipment.

\section{HPLC determination}

HPLC was performed on the GBC system (GBC, Dandenong, Victoria, Australia) equipped with a HPLC pump (LC 1110) and, a fluorescence detector (model LC 1255) at wavelengths of 332 and $476 \mathrm{~nm}$ for excitation and emission, respectively. The LC column was a LiChrosorb $\mathrm{C}_{18}(250 \mathrm{x} 4 \mathrm{~nm}, 10 \mu \mathrm{m}$ - Merck, Darmstadt, Germany). The mobile phase consisted of a mixture of acetic acid 3.33\% aqueous solution, acetonitrile, methanol (30:35:35), the flow rate was $0.8 \mathrm{~mL} / \mathrm{min}$. The linearity was determined to be in the range of $2-256 \mathrm{ng} / \mathrm{mL}$ of OTA. Confirmation of the identification of OTA was determined by methyl ester formation, in accordance with AOAC (1).

\section{Recovery experiments}

Recovery tests were performed by spiking OTA in uncontaminated wine and grape juice samples. For wine samples the OTA concentration levels were $0.03,2$, and $5 \mathrm{ng} / \mathrm{mL}$ and for grape juice it was at $0.4 \mathrm{ng} / \mathrm{mL}$. The samples were analyzed in triplicate.

\section{RESULTS AND DISCUSSION}

\section{Analytical}

For HPLC, the calibration curve obtained by least-squares linear regression was linear at $2-256 \mathrm{ng} / \mathrm{mL}$ and the correlation coefficient was 0.99998 . The recoveries for red wine samples were $94.1,82.5$, and $86 . \%$ and the relative standard deviations (RSD) were $6.10,1.03,4.1 \%$ at levels of $0.03,2.0,5.0 \mathrm{ng} / \mathrm{mL}$, respectively. For grape juice, the recovery was $86.2 \%$ and the RSD was $2.0 \%$ at a level of $0.4 \mathrm{ng} / \mathrm{mL}$. The detection limit (LOD) was established $0.01 \mathrm{ng} / \mathrm{mL}$ determined by repeat analysis of a blank matrix and is the analyte concentration whose result is equivalent to the mean blank response plus 3 standard deviations and quantification limit (LOQ) established was $0.03 \mathrm{ng} / \mathrm{mL}$ defined as the minimum level at which the analyte can bee quantified with acceptable accuracy and precision (11).

Fig. 1 shows the resulting chromatograms of (a) standard solution containing $40 \mathrm{ng} / \mathrm{mL}$ of OTA and derivatized OTA standard; (b) red wine sample naturally contaminated with 0.23 $\mathrm{ng} / \mathrm{mL}$ and derivatized red wine sample.

\section{Occurrence}

This survey utilized red wine to study OTA contamination considering information that the red wines is most consumed in Brazil (8), and well previous reports from other countries have indicated that red wine is more susceptible to this contamination $(16,26)$. 


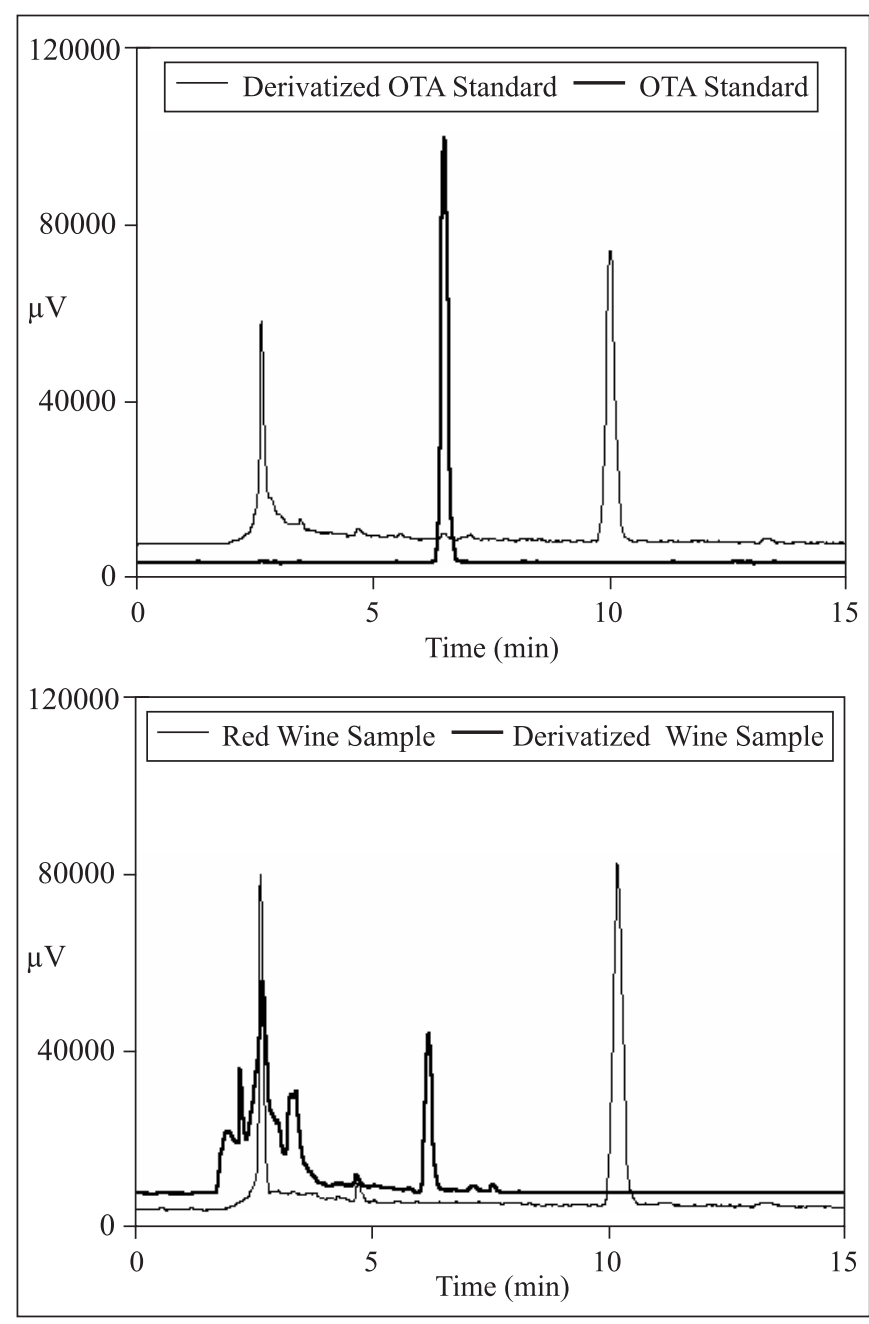

Figure 1. (a) chromatograms of standard solution containing $40 \mathrm{ng} / \mathrm{mL}$ of OTA (corresponding to $0.6 \mathrm{ng} / \mathrm{g}$ of OTA) and derivatized OTA standard; (b) chromatograms of red wine sample naturally contaminated with $0.23 \mathrm{ng} / \mathrm{mL}$ and derivatized red wine sample.

The results from 63 red wine and 38 grape juice samples are summarized in Table 1. OTA contamination was found in 27 (42.9\%) samples analysed. In 29 Brazilian wines, 09 (31\%) presented OTA contamination at concentrations that ranged from 0.10 to $1.33 \mathrm{ng} / \mathrm{mL}$. The analysis of 34 imported wines revealed OTA contamination in 18 (52.9\%) samples, ranging from 0.03 to $0.32 \mathrm{ng} / \mathrm{mL}$. OTA was not detected in any of the grape juice samples analysed.

In 2003, the wine and must production in Brazil was about 330.000 .000 liters. The state of Rio Grande do Sul (latitude $29^{\circ} \mathrm{S}$, longitude $51^{\circ} \mathrm{W}$ ) is considered the most important wineproducing region, representing about $95 \%$ of national production. In this location, OTA was detected in 2 (22) samples
Table 1. Ochratoxin A levels and frequency of occurrence in red wines from Brazil and others countries.

\begin{tabular}{lccc}
\hline \multicolumn{1}{c}{ Country } & $\begin{array}{c}\text { Number of } \\
\text { samples } \\
\text { Analized }\end{array}$ & $\begin{array}{c}\text { Number of } \\
\text { samples } \\
\text { detected }(\%)\end{array}$ & $\begin{array}{c}\text { Range } \\
\text { of OTA } \\
(\mathrm{ng} / \mathrm{mL})\end{array}$ \\
\hline \multicolumn{1}{c}{ southern region } & 22 & $02(6.9)$ & $0.10-0.24$ \\
$\begin{array}{c}\text { Brazil } \\
\quad \text { northeastern region }\end{array}$ & 07 & $07(100)$ & $0.36-1.33$ \\
Chile & 07 & 0 & $\mathrm{ND}$ \\
Argentina & 06 & $01(16.7)$ & $<0.03$ \\
Uruguay & 03 & $01(33.3)$ & $<0.03$ \\
France & 05 & $03(60.0)$ & $0.20-0.29$ \\
Italy & 05 & $05(100)$ & $0.03-0.32$ \\
Portugal & 05 & $05(100)$ & $0.03-0.25$ \\
Spain & 02 & $02(100)$ & $0.07-0.12$ \\
South Africa & 01 & $01(100)$ & $<0.03$ \\
\hline
\end{tabular}

$\mathrm{ND}=$ Not detected $($ Limit of detection $=0.01 \mathrm{ng} / \mathrm{mL})$.

at concentrations of 0.10 and $0.24 \mathrm{ng} / \mathrm{mL}$. The highest level $(1.33$ $\mathrm{ng} / \mathrm{mL}$ ) was found in wine produced in the São Francisco Valley, located in northeast region of Brazil (latitude $9^{\circ} \mathrm{S}$, longitude $40^{\circ} \mathrm{W}$ ) of which all samples (7) were contaminated with OTA at concentrations ranging from 0.36 to $1.33 \mathrm{ng} / \mathrm{mL}$. According to the label information, the wine was produced with following types of grapes: Syraz, Petit Syraz, Cabernet Sauvignon and Tannat. The OTA contamination of wines from the São Francisco Valley could be attributed to the type of grape, mould population on ripe grapes and/or climate. These factors could explain the difference in OTA contamination in the red wine samples analysed from both regions, south and northeast of Brazil.

The samples of imported red wines analysed in this investigation revealed a high incidence with low levels of OTA in European countries, mainly in the Mediterranean ones, and low incidence and levels in South American countries (Argentina, Chile and Uruguay).

In Brazil, Rosa et al. (19) analysed wine, grape juice and frozen pulp samples commercialized in the city of Rio de Janeiro. In this study, of a total of 80 samples of national and imported wine, $28.75 \%$ were contaminated with OTA, at concentrations ranging from 0.021 to $0.071 \mathrm{ng} / \mathrm{mL}$, with an average of $0.034 \mathrm{ng} /$ $\mathrm{mL}$. Out of the 64 grape juice and frozen pulps samples, $25 \%$ were contaminated with OTA, at concentrations ranging from 0.021 to $0.1 \mathrm{ng} / \mathrm{mL}$, with an average of $0.037 \mathrm{ng} / \mathrm{mL}$.

OTA contamination in Brazilian wines could be considered low in comparison with other countries, mainly in southern and western Europe, northern and southern Africa $(16,22)$. In these regions, a high incidence of OTA in red wines has been observed, in varied concentrations. Zimmerli and Dick (26) in a preliminary survey on wines obtained from Swiss retail markets, observed 
that the OTA contents of wines from southern wine-growing regions are higher than those in wines from the northern region. Otteneder and Majerus (16) supported this investigation and concluded that the geographic region of origin has a strong influence on OTA contamination. Pietri et al. (18) in a survey study conducted in Italy showed that OTA levels are high in wines produced in areas with warm climatic conditions, suggesting that OTA production could be due to fungi belonging to the genus Aspergillus.

Table wine represents $80 \%$ of Brazilian production. The predominating cultures are the American (Vitis labrusca, Vitis bourquina) and Hybrids grapes. There are a few segments of viti and viniproducers producing high quality wines by implementing Vitis vinifera vineyards and high technological processes. Based on the red wines samples taken in this survey, the occurrence of OTA does not appear to be a public health hazard, according to the Comission Regulation EC 123/2005 (7).

OTA was not detected in any of the total 38 grape juices analysed in this study. This result can be attributed to several factors such as type of grape, different geographic regions, temperate or warmer regions, different practices used in grape cultivation. However, little information is available in the literature on OTA in grape juice to support this hypotesis $(2,19,26)$.

The Scientific Committee on Food of the European Commission (6) has set a Tolerable Daily Intake (TDI) for OTA of $5 \mathrm{ng} / \mathrm{kg}$ b.w./day. Considering the wine consumption in Brazil, $5 \mathrm{~mL} /$ day (8), the highest level found in the present study (1.33 $\mathrm{ng} / \mathrm{mL}$ ), and an average body weight (b.w.) of $70 \mathrm{~kg}$, the overall concentration in the São Francisco Valley accounts for $0.096 \mathrm{ng} /$ $\mathrm{kg}$ b.w./day (1.92\% of TDI). For the WHO Committee of Experts on Food Additives and Contaminants (3), which established a TDI for OTA of $14 \mathrm{ng} / \mathrm{kg}$ b.w./day, the daily intake of OTA is estimated to be $0.68 \%$ of the Tolerable Daily Intake.

Therefore, according to our study, the contribution to daily intake from Brazilian red wines could be considered lower than wines from both Mercosul countries and traditional wine producing countries. Since the consumption of wine in Brazil is increasing, controlling the level of OTA in the wines consumed in our country is necessary to guarantee a product without contamination for decreasing the health risks.

Knowledge of the extent of OTA contamination in Brazilian wines is important to establish national regulations. In addition, this data is significant toward improving the quality of the final product in order to increase exports.

\section{RESUMO}

\section{Ocratroxina A em vinhos e sucos de uva comercializados na cidade de São Paulo, Brasil}

Durante o verão de 2005, um total de 101 amostras de vinho tinto e suco de uva, compradas em supermercados e lojas especializadas na cidade de São Paulo, foram analisadas para a presença de Ocratoxina A (OTA). OTA foi pesquisada em 29 amostras de vinho tinto e 38 de suco de uva produzidos no Brasil e em 34 amostras importadas de vinho tinto (provenientes da Argentina, Chile, Uruguai, França, Itália, Portugal, Espanha e África do Sul). OTA foi extraída em coluna de imunoafinidade e detectada por CLAE com detector de fluorescência, de acordo com EN 14133/2003. Os limites de deteç̧ão e quantificação estabelecidos foram 0,01 e $0,03 \mathrm{ng} /$ $\mathrm{mL}$, respectivamente. Os percentuais médios de recuperação das amostras de vinho tinto foram de 94,$1 ; 82,5 ; 86,1 \% \mathrm{com}$ coeficientes de variação de 6,$10 ; 1,03 ; 4,11 \%$ para os níveis de 0,$03 ; 2,0 ; 5,0 \mathrm{ng} / \mathrm{mL}$, respectivamente. Para suco de uva, o percentual médio de recuperação foi de $86,2 \%$, com coeficiente de variação de $2.01 \%$ para o nível $0.4 \mathrm{ng} / \mathrm{mL}$. Os resultados de análise demonstraram uma contaminação por OTA em 9 das 29 amostras de vinho tinto provenientes do Brasil, com níveis de contaminação variando de 0,10 a $1,33 \mathrm{ng} / \mathrm{mLe}$ em 18 de 34 amostras de vinho tinto importado, com níveis variando de 0,03 a $0,32 \mathrm{ng} / \mathrm{mL}$. OTA não foi detectada em nenhuma amostra de suco de uva analisada. Embora os resultados das amostras de vinho analisadas para a presença de OTA estejam inferiores aos limites máximos estabelecidos pela Comunidade Européia - EC 123/2005 (2,0ng/mL), uma exposição pequena e contínua por essa micotoxina pode trazer um sério risco à saúde humana.

Palavras-chave: Ocratoxina A, vinho tinto, suco de uva, coluna de imunoafinidade, determinação por CLAE

\section{REFERENCES}

1. AOAC. Official Methods of Analysis. $16^{\text {th }}$ ed. Washington, DC: Association of Official Analytical Chemists, 1997, chapter 49, pp. 37-38, 41 .

2. Battilani, P.; Pietri, A.; Bertuzzi, T.; Languasco, L.; Giorni, P.; Kozakiewicz, Z. Occurrence of ochratoxin A-producing fungi in grapes grown in Italy. J. Food Protect., 66, 633-6, 2003.

3. Benford, D.; Boyle, C.; Dekant, W.; Fuchs, R.; Gaylor, D.W.; Hard G.; Mc Gregor, D.B.; Pitt, J.I.; Plestina, R.; Shephard, G.; Solfrizzo, M.; Verger, P.J.P.; Walker, R.; Ochratoxin A. In Safety Evaluation of Certain Mycotoxins in Food; WHO Food Additives Series 47; FAO Food and Nutrition Paper 74; WHO: Geneva, Switzerland, 2001, p.281-415.

4. Blesa, J.; Soriano, J.M.; Molto, J.C.; Manes, J. Concentration of ochratoxin $\mathrm{A}$ in wines from supermarkets and stores of Valencian Community (Spain). J. Chromatogr., 1054, 397-401, 2004.

5. Cabañes, F.J.; Accensi, F.; Bragulat, M.R.; Abarca, M.L.; Castellá, G.; Minguez, S.; Pons, A. What is the source of ochratoxin A in wine? Int. J. Food Microbiol., 79, 213-5, 2002.

6. Comission of the European Communities, Directorate General XXIV, Scientific Committee on Food, Outcome of discussions 14, expressed on 17 Sept, 1998.

7. Comission Regulation (EC) $\mathrm{N}^{\circ} 123 / 2005$ of January amending Regulation (EC) $\mathrm{N}^{\mathrm{o}} 466 / 2001$ as regards ochratoxin A. Official J. European Union L 25 (2005) 3-5.

8. Embrapa Uva eVinho. http://www.cnpuv.embrapa.br (13/08/2005) 
9. EN 14133. British Standard. Foodstuffs - Determination of ochratoxin A in wine and beer - HPLC method with clean-up on a immunoaffinity column clean-up, 2003.

10. Filali, A.; Ouammi, L.; Betbeder, A.M.; Baudrimont, I.; Soulaymani, R.; Benayada, A.; Creppy, E.E. Ochratoxin A in beverages from Morocco: a preliminary survey Food Addit. Contam., 18, 565-8, 2001.

11. Garfield, F.M.; Klesta, E.; Hirsh, J. Quality Assurance Principles for Analytical Laboratories. AOAC International $3^{\text {rd }}$ ed. Gaithersburg, MD: Association of Official Analytical Chemists. 2000, p.122.

12. IARC. Ochratoxin A.; IARC Monographs on the Evaluation of Carcinogenic Risks to Humans, Some Naturally Occurring Substances: Food Items and Constituents, Heterocyclic Aromatic Amines and Mycotoxins, Vol. 56; International Agency for Research on Cancer: Lyon, France, 1993, p.489-521.

13. Lopez de Cerain, A.; Gonzáles-Penas, E.; Jimenez, A.; Bello, J. Contribution to the study of ochratoxin A in Spanish wines. Food Addit. Contam., 19, 1058-64, 2002.

14. Markaki, P.; Delpont-Binet, C.; Grosso, F.; Dragacci, S. Determination of ochratoxin A in red wine and vinegar by immunoaffinity highpressure liquid chromatography. J. Food Protect., 64, 533-537, 2001.

15. Marquardt, R.R.; Frohlish, A.A. A review of recent advances in understanding ochratoxicosis. J. Anim. Sci., 70, 3968-88, 1922.

16. Otteneder, H.; Majerus, P. Occurrence of ochratoxin A (OTA) in wines: influence of the type of wine and its geographic origin. Food Addit. Contam., 17, 793-8, 2000.

17. Petkova-Bocharova, T.; Castegnaro, M. In: Castegnaro, M.; Plestina, R.; Dirheimer, G.; Chernozemsky, I.N.; Bartsch, H. (eds). Mycotoxins, Endemic Nephropathy and Urinary Tract Tumours. IARC Scientific Publications 115; IARC press: Lyon, France, 1991, p.159-164.
18. Pietri, A.; Bertuzzi, T.; Pallaroni, L.; Piva, G. Occurrence of ochratoxin A in italian wines. Food Addit. Contam., 18, 647-57, 2001.

19. Rosa, C.A.; Magnoli, C.E.; Fraga, M.E.; Dalcero, A.M.; Santana, D.M. Occurrence of ochratoxin A in wine and grape juice marketed in Rio de Janeiro, Brazil. Food Addit. Contam., 21, 358-64, 2004.

20. Sáez, J.M.; Medina, A.; Gimeno-Adelantado, J.V.; Mateo, R.; Jiménez, M. Comparison of different sample treatments for the analysis of ochratoxin A in must, wine and beer by liquid chromatography. $J$. Chromatogr., 1029, 125-33, 2004.

21. Schlatter, Ch.; Studer-Rohr, J.; Rasonyi, Th. Carcinogenicity and kinetic aspects of ochratoxin A. Food Addit. Contam., 13 (Suppl.), 43-4, 1996

22. Shephard, G.S.; Fabiani, A.; Stockenström, S.; Mshicileli, N.; Sewram, V., Quantitation of Ochratoxin A in South African Wines. J. Agric. Food Chem., 51, 1102-6, 2003.

23. Stefanaki, I.; Foufa, E.; Tsatsou-Dritsa, A.; Dais, P. Ochratoxin A concentrations in Greek domestic wines and dried vine fruits. $J$. Food Protect., 20, 74-83, 2003.

24. Visconti, A.; Pascale, M.; Centonze, G. Determination of ochratoxin A in wine by means of immunoaffinity column clean-up and highperformance liquid chromatography. J. Chromatogr., 864, 89-101, 1999.

25. World Health Organization. Ochratoxin A - Toxicological Evaluation of Certain Food Additives and Contaminants; WHO Food Additives Series 35; WHO: Geneva, Switzerland, 1996, p.363-376.

26. Zimmerli, B.; Dick, R. Ochratoxin A in table wine and grape-juice: occurrence and risk assessment. Food Addit. Contam., 13, 655-68, 1996. 